\title{
A Fixer's Dress Code: Surface Polysaccharides and Host-Plant-Specificity in the Root Nodule Symbiosis
}

\author{
黒幕による服装指定：根粒共生における表面多糖と宿主植物特異性 \\ Laus, Marc C. ; and Kijne, Jan W. \\ Institute of Biology Leiden, Clusius Laboratory, Wassenaarseweg 64, 2333 AL Leiden, The Netherlands \\ FAX: 31-71-5276997, E-mail: j.kijne@ science.leidenuniv.nl
}

Key Words: rhizobium, lectin, surface polysaccharides, attachment, root infection

\begin{abstract}
Rhizobium bacteria interact with leguminous plants to form symbiotic nitrogen-fixing root nodules. Rhizobia present a mosaic of surface polysaccharides, each of which specifically involved in plant root colonisation, attachment and infection. This review describes the situation for R.leguminosarum biovar viciae, a symbiote of pea and vetch, for which seven surface polysaccharides have now been characterized. Special attention is given to interactions with specific legume lectins at the root surface, in relation to host-plant-specificity of the root nodule symbiosis.
\end{abstract}

要 約

根粒細菌はマメ科植物と相互作用し、窒素固定を行う共生 組織である根粒を形成する。根粒細菌の表面は多糖のモザイク となっており、それぞれの多糖が植物の根への移住、接着、感 染に特異的に関わっている。本総説ではエンドウ、カラスノエ ンドウの共生体であり、7 種類の表面多糖の性質が解明されて いる R.leguminosarum biovar viciae 取り上げて、研究の現状を述 べる。宿主植物特異性と関連させつつ、根の表面でのマメ科特 有のレクチンとの相互作用に特に注目して述べる。

\section{A. Root Nodule Formation}

Root nodules are special organs on the roots of a plant, in which symbiotic bacteria process dinitrogen into ammonia for the benefit of the plant. Plants with efficient root nodules can grow independently from external nitrogen fertilizer. Many nodulated plants are valuable crops. Symbiotic dinitrogen fixation is pivotal in the nitrogen cycle of the biosphere, and contributes to a non-polluting and inexpensive agricultural practice.

For leguminous plants (Fabaceae), such as pea, vetch, bean and soybean, the symbiotic bacteria belong to the family of Rhizobiaceae. The processes of rhizobial root infection and root nodule formation (nodulation) are host-plant-specific. For example, Bradyrhizobium japonicum nodulates soybean but not pea, whereas Rhizobium leguminosarum biovar viciae is the symbiotic partner of pea and vetch but does not infect soybean roots. Host-plant-specificity is determined at an early stage in the nodulation process. A plant-specific blend of phenolic compounds in the root exudate stimulates expression of rhizobial nodulation (nod) genes. These genes encode enzymes of a biosynthetic pathway, resulting in the production of lipochitin oligosaccharides (LCOs), also called Nod factors. These Nod factors are signal molecules essential for the nodulation process. They are readily recognized by host plants and poorly, if at all, by nonhost plants $(1,2)$.

Nod factors induce various responses in host plant roots:

\section{A. 根粒の形成}

根粒は植物の根に生じる特殊な器官であり、そこで共生細 菌が植物のために窒素分子をアンモニアへ変換する。効率の良 い根粒を備えた植物は、外来の窒素供給源なしに成長できる。 根粒を持った植物の多くが貴重な作物である。共生による窒素 の固定は生物圏における窒素サイクルのかなめとなり、環境污 染のない経済的な農業を実施することに貢献できる。

エンドウ、カラスノエンドウ、ダイズなどのマメ科植物 (Fabaceae) に対する共生細菌は Rhizobiaceae に属する。根粒細 菌の根への感染と根粒形成は宿主植物特異的である。例えば、 Bradyrhizobium japonicum はダイズに根粒を作るが、エンドウに は作らない。一方、Rhizobium leguminosarum bivor Viciae はエン ドウおよびカラスノエンドウの共生パートナーであるが、ダイ ズの根には感染しない。宿主特異性は根粒形成の初期に決定さ れる。根からしみ出すフェノール性化合物の混合割合は植物種 に固有であり、根粒細菌の根粒形成遺伝子群 (nod) の発現を促 進する。これらの遺伝子は一連の生合成経路に関わる醭素を コードしており、その結果、Nod 因子と呼ばれるリポキチンオ リゴ多糖 (LCOs) が生産される。これらの Nod 因子は根粒形成 に不可欠なシグナル分子であり、宿主植物によって容易に認識 されるが、非宿主植物によってはほとんど、あるいはまったく 認識されない $(1 、 2)$ 。

Nod 因子は宿主植物の根に、根毛形成、根毛変形、皮層細 
Trends in Glycoscience and Glycotechnology Vol.16 No.90 (July 2004) pp.281-290

root hair formation, root hair deformation, polarization of cortical cells, and cell divisions in the root cortex. Usually, young growing root hairs are target cells of rhizobial infection. However, production of Nod factors is insufficient for root infection to occur. Infection of a root hair is only possible if production of Nod factors is combined with efficient attachment of the bacteria to the root hair tip (3). Attachment of Nod factor-producing rhizobia to the tip of young growing root hairs of a host plant is followed by tight curling of the hair around the tip-bound bacteria. In the root hair curl, bacterial cell divisions yield a so-called infection focus. From this focus, the rhizobia infect the root through an infection thread, an intracellular tip-growing plant membrane structure with a wall and a matrix consisting of, among others, plant derived glycoproteins (4). In many cases, infection thread formation is enabled by polarization of cortical cells, the formation of cytoplasmic bridges $(5,6)$. From the growing and ramifying infection thread, the rhizobia eventually invade the cells of the young root nodule, and differentiate into dinitrogenfixing bacteroids (for a review, see 7).

Usually, rhizobia can attach to root hairs of nonhost legumes but do not induce tight root hair curling and formation of infection foci and infection threads. This suggests that the inability of rhizobia to nodulate a nonhost plant may result from (i) an inability to recognize a certain blend of phenolics, (ii) production of incompatible LCOs, or (iii) inefficient attachment to the root hair. Many observations convincingly support the first two suggestions. However, rhizobial attachment as a determinant of host-plant-specificity is still a matter of debate. On the other hand, presence of a variety of nod genes enables the bacterial symbiote to respond to various phenolics and to produce a cocktail of different Nod factors. In combination with a general and efficient attachment mechanism, such rhizobia can have a broad host plant range. A well-known example is Rhizobium sp. NGR 234 which is able to nodulate many different legumes.

\section{B. Root Hair Attachment}

Rhizobial attachment to plant root hairs appears to be a multi-step process (for reviews, see 8-10). Direct attachment to the root hair surface is followed by accumulation and anchoring. In both steps, different mechanisms can be involved.

One attachment mechanism, common among Rhizobiaceae (including the crown-gall bacterium Agrobacterium tumefaciens), involves a calcium-dependent bacterial adhesin, called rhicadhesin. Rhicadhesin-mediated binding of Rhizobiaceae was found with a variety of plants, including monocotyledonous species (11). The identity of the putative plant receptor remains to be established. A second attachment mechanism is based on crossbridging and gelling of acidic polysaccharides on both the plant and the bacterial surface by $\mathrm{Ca}^{2+}$ ions (12). A third attachment mechanism involves lectin molecules on the root hair surface. Lectins are proteins with at least one noncatalytic carbo-
胞の極性化、根の皮層における細胞分裂など、さまざまな応答 を誘導する。根粒細菌が感染するための標的はふつう若い成長 途上の根毛である。しかし Nod 因子の生産だけでは感染成立に は十分でない。Nod 因子生産と同時に、細菌が根毛先端へ効率 的に接着することによって初めて感染が成立する (3)。Nod 因子 を生産する根粒細菌が宿主植物の若い成長途上の根毛に接着す ることに引き続いて、先端に結合した細菌のまわりに根毛が固 く巻いたカールを作る。根毛のカールの中で細菌細胞が分裂し て、いわゆる感染中心を作る。根粒細菌はこの中心から感染線 維を介して感染する。これは植物由来の糖タンパク質その他を 成分とする、壁㧍よびマトリックスとからなる細胞内膜構造物 で、先端が伸びて行く (4)。感染線維の形成は多くの場合、皮層 細胞の極性化、すなわち細胞質ブリッジの形成、によって可能 になる $(5 、 6)$ 。伸長し枝分かれする感染線維から、根粒細菌は最 終的に若い根粒中の細胞に侵入し、窒素分子を固定するバクテ ロイドに分化する(総説として 7 を参照)。

根粒細菌はふつう非宿主植物の根毛にも接着できるが、根 毛の固いカールの形成や、感染中心および感染線維の形成を誘 導しない。根粒細菌が非宿主細胞に根粒を作れない理由として は、(i) 特定の混合割合のフェノール性化合物を認識できない、 (ii) 適合性のない LCOs を産生する、あるいは (iii) 根毛への接 着効率が悪い、などが考えられる。多くの観察から、後の $2 つ$ の可能性が高い。しかし宿主植物特異性の決定的要因を、根粒 細菌の接着段階とすることには依然として議論がある。一方、 共生細菌にはさまざまな nod 遺伝子が存在するので、様々な フェノール化合物に応答でき、異なる Nod 因子の混合物を生産 できる。このような根粒細菌は普遍的でかつ効率的な接着機構 を合わせ持つことによって、広い範囲の植物を宿主とすること ができる。よく知られた例としては Rhizobium sp. NGR234 があ り、さまざまなマメ化植物に根粒を作ることができる。

\section{B. 根毛への接着}

植物根毛への根粒細菌の接着は多段階過程らしい(総説とし ては 8 参照)。根毛表面への直接的な接着に続いて、累積と固着 が起こる。どちらの過程にもいくつかの異なる機構が考えられ ている。

接着のひとつの機構として、Rhizobiaceae (クラウンゴール 細菌 Agrobacterium tumefacienc も含む) に共通するものは、カル シウム依存性の細菌アドヘシンであるリカドヘシンの関与であ る。リカドヘシンを介した Rhizobiaceae の結合は、単子葉植物 種も含む多様な植物で見出されている (11)。植物中のレセプ タ一候補は未確認である。第二の接着機構は $\mathrm{Ca}^{2+}$ イオンによる 植物および細菌の表面にある酸性多糖の架橋とゲル化を土台と している (12)。第三の接着機構は、根毛表面レクチン分子の関 与である。レクチンは触媒活性を持たない糖結合領域を少なく 
hydrate-binding domain (13). Lectins involved in rhizobial attachment belong to a family of lectins, commonly called legume lectins. To distinguish this family from other types of legume lectins, we refer to this family as Candy lectins. This name is based on conserved and essential elements in the carbohydratebinding site of these proteins: a $\mathbf{C a}^{2+}$ ion, an Asn (N) and an Asp (D) residue, and a hydrophobic amino acid (Tyr, $\mathbf{Y}$, in concanavalin A) (14). Candy lectins produced by different legumes have different carbohydrate-binding specificities. For example, soybean lectin is N-acetyl-D-galactosamine/D-galactose-specific, whereas pea lectin binds D-mannose and D-glucose. Candy lectins are secreted from young root hairs (Figure 1). Being present at the root hair surface with carbohydrate-binding sites available (15), lectin molecules can mediate direct attachment of rhizobia, provided that the bacteria expose the corresponding carbohydrates on their surface. In contrast to rhicadhesin-mediated attachment, lectin-mediated attachment is essentially hostplant-specific. In 1974, Bohlool and Schmidt (16) reported that 23 of 25 Bradyrhizobium japonicum strains (soybean rhizobia) were able to bind soybean lectin, whereas this protein preparation did not bind to other rhizobial species. Furthermore, host plants of R. leguminosarum biovar viciae (pea, vetch, lentil and sweet pea) all produce a conserved group of lectins with a carbohydrate-binding specificity different from that of Candy lectins produced by other host plants. However, any bacterium that exposes the corresponding carbohydrate ligand in its surface polysaccharides can show lectin-mediated attachment on legume root hair tips.

Candy lectins are multivalent and possess two or more carbohydrate-binding sites. Consequently, secreted Candy lectins can also mediate accumulation of rhizobia on root hair tips by connecting attached bacteria to other bacteria (17). In addition, rhizobial aggregates can be formed with bacterial cellulose fibrils
とも 1 カ所の持つタンパク質である (13)。根粒細菌の接着に関 わるレクチンは、いわゆるマメ科レクチンと呼ばれるファミ リーに属している。このファミリーをそれ以外のマメ類のレク チンから区別するために、以後 Candy レクチンと呼ぶことにす る。これらのタンパク質の糖結合部位にとって不可欠な、保存 されている要素がこの名前の土台である：Ca $\mathbf{a}^{2+}$ イオン、Asn (N) およびAsp (D) 残基、1 個の疎水性アミノ酸 (Y すなわち Tyr、 コンカナバリンA の場合)。各種のマメ科植物が作る Candy レク チンの糖結合特異性は異なっている。例えば、ダイズレクチン は $N$-アセチル-D-ガラクトサミン/D-ガラクトース特異的である が、エンドウレクチンはD-マンノースおよびD-グルコースを結 合する。Candy レクチンは若い根毛から分泌される (図 1)。根 毛表面でレクチン分子の糖結合部位は機能を発揮できる状態に あり、根粒細菌が対応する糖鎖を表面に露出しさえすれば、細 菌が直接に結合できるよう仲介しうる。レクチンを介した接着 は本質的に宿主植物に特異的であり、リカドヘシンを介した接 着とは対照的である。1974 年にBohlool と Schmid が Bradyrhizobium japonicum (ダイズの根粒細菌)の 25 種のうちの 23 種がダイズレクチンに結合できるが、それ以外の根粒細菌は このレクチンに結合しないことを報告した(16)。更に $R$. leguminosarum bivor Viciae の宿主植物 (エンドウ、カラスノエン ドウ、スイートピー)の全てが、保存されたグループのレクチン を作るが、それらの糖結合特異性は他の宿主植物が作る Candy レクチンとは異っている。しかし表面多糖上に対応する糖鎖り ガンドを露出できる全ての細菌は、マメ科植物根毛先端ヘレク チンを介して接着できる。

Candy レクチンは多価であり、二つ以上の糖結合部位を持 つ。その結果、分泌されたCandy レクチンは、根毛先端上で接 着した細菌を別の細菌と更に接着させて根粒細菌が積み重なる ことも仲介する (17)。その上、根粒細菌の凝集体は細菌のセル

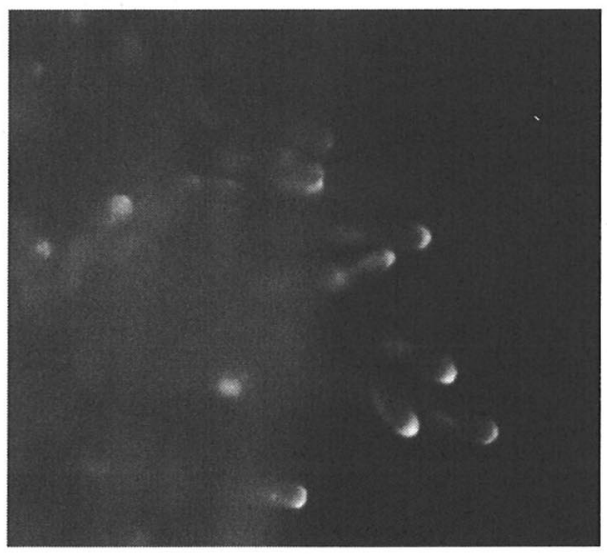

Fig. 1. Presence of pea lectin on the tips of pea root hairs as shown by indirect immunological visualization techniques using anti-pea lectin antibodies. Picture by Dr. Clara Díaz. 
$(18,19)$.

Cellulose fibrils also anchor Rhizobiaceae to the plant cell surface (8-10). In the soybean symbiosis, this process is mediated by bacterial fimbriae $(20,21)$. Possibly, soybean rhizobia do not produce cellulose fibrils (18). Cellulose-mediated anchoring of rhizobia to the root hair surface may be required for infection of fast growing root hairs, being not essential for infection of just emerging root hairs (22).

Presence of a variety of attachment mechanisms suggests that rhizobia can adapt to different growth conditions. For example, pea and vetch prefer slightly acidic conditions for optimal nodulation. Because rhicadhesin-mediated attachment is acid-sensitive $(10,23)$, this type of attachment may be useful under suboptimal, more alkaline conditions.

\section{Surface Polysaccharides}

Rhizobium bacteria produce a variety of surface polysaccharides. Not all of these are involved in attachment. As an illustration, we will describe the situation with $R$. leguminosarum biovar viciae ( $R l v)$ strain RBL5523. The $R l v$-pea/vetch combination is the only symbiotic interaction for which the surface polysaccharide-lectin situation has been fairly well characterized (22).

RBL5523 has originally been isolated as an $R$. leguminosarum biovar trifolii (a clover symbiote) strain. However, the so-called Symbiosis (Sym)-plasmid carrying the clover-specific nod genes has been removed and replaced by a Sym plasmid with pea/vetch-specific nod genes. As a result, host plants of this strain are vetch, pea, lentil and sweet pea. RBL5523 produces (at least) seven different surface polysaccharides, EPS, CPS, LPS, GPS, a glucomannan, $\beta$-1,2-glucan, and cellulose.

\section{EPS}

Like many $R$. leguminosarum strains, RBL5523 secretes an acidic extracellular polysaccharide (EPS) consisting of octasaccharide repeating units (24). Each unit contains glucose, glucuronic acid and galactose in a 5:2:1 ratio, with acetyl, pyruvyl and hydroxybutanoyl substitutions $(25,26)$. EPS is not a ligand of pea lectin (PSL), which follows from its structure. In order to fit in the PSL carbohydrate-binding site, a mannose or glucose residue must have free hydroxyls at C4 and C6 (27). Such a residue is absent in EPS. EPS of RBL5523 is primarily involved in infection thread formation (28). The structure of EPS is common for $R$. leguminosarum biovars, regardless of the nod genes present (29).

\section{$C P S$}

From the surface of RBL5523, a capsular polysaccharide (CPS) can be isolated with a structure identical to that of EPS (22). It is unknown which mechanism is responsible for retention of the polysaccharide on the bacterial surface. Possi-
ロース線維によっても作られる。

セルロース線維もまた根粒細菌を植物細胞表面へ固着させ る(8-10)。ダイズの共生においては、この過程は細菌の線毛を 介しておこる $(20 、 21) 。$ ダイスの根粒細菌はおそらくセルロース を作らない (18)。セルロースを介した根粒細菌の根毛表面への 固着は、急速に成長しつつある根毛で要求されるもので、伸び 始めたばかりの根毛への感染には必須ではないようである (22)。

様々な接着機構があることで、根粒細菌は様々な生育条件 に適応しうるものと思われる。例えばエンドウやカラスノエン ドウでは、やや酸性の条件の方が根粒形成に適している。リカ ドヘシンを介した接着は酸に敏感なので $(10 、 23)$ 、最適条件から やや離れたアルカリ性の条件下ではこの型の接着の方が有用な のかも知れない。

\section{C. 表面多糖}

根粒細菌は様々な表面多糖を生産する。これらの全てが接 着に関与するわけではない。説明のため、R. leguminosarum bivor viciae $(R l v)$ 株 RBL5523 の場合を取りあげよう。Rlvとエンドウ /カラスノエンドウの組合せは、表面多糖とレクチンの関係がか なりよく解析されている共生相互作用の例として唯一のもので ある (22)。

RBL5523 は最初は R. leguminosarum bivor trifolii 株 (クロー バーの共生者) として分離された。しかしクローバー特有の遺伝 子 nod を運ぶいわゆる共生 (Sym)-プラスミドが取り除かれて、 エンドウ/カラスノエンドウ特有の nod 遺伝子を運ぶ Sym プラ スミドで置換された。その結果、この株の宿主植物はカラスノ エンドウ、エンドウ、レンズマメ、スイートピーとなってい る。RBL5523 は少なくとも 7 種の異なる多糖、EPS、CPS、


スを作る。

\section{EPS}

多くの R. leguminosarum 株と同様に、RBL5523 は八糖の繰 り返し構造をもつ酸性の細胞外多糖 (EPS) を分泌する (24)。各 単位には、アセチル、ピルビルまたはヒドロキシブタノイル基 で置換されたグルコース、グルクロン酸、ガラクトースが $5: 2$ :1の比率で含まれる $(25 、 26)$ 。 EPS はその構造からしてエンド ウレクチン (PSL) のリガンドではないと考えられる。PSL の糖 結合部位に適合するためには、マンノースあるいはグルコース 残基の $\mathrm{C} 4$ および $\mathrm{C} 6$ の $\mathrm{OH}$ 基が遊離している必要があるが(27)、 EPS にはこのような残基が存在しない。RBL5523の EPS は感 染線維形成に当初から関わっている (28)。EPS の構造は nod 遺 伝子の有無に関わらず R. leguminosarum biovars に共通している (29)。

\section{CPS}

RBL5523 の表面から、EPS と同じ構造を持つカプセル多糖 (CPS) を単離できる (22)。どのような機構で細菌表面に多糖を 保持しているのかは不明である。カルシウムによる架橋、ある 
bilities are calcium cross-bridging and/or hydrophobic interactions between hydroxybutanoyl groups and lipopolysaccharide (LPS). At present, it is impossible to decide whether EPS or CPS or both are required for infection thread formation. As judged from a reduced number of infection foci, EPS/CPS-deficient mutants show reduced attachment to root hair tips (28). A CPS-capsule may mask cellulose fibrils on the bacterial surface, preventing cellulose-mediated flocculation of bacteria (22).

\section{$L P S$}

Rhizobiaceae are Gram-negative bacteria, and their outer membrane contains lipopolysaccharide (LPS). LPS of $R$. leguminosarum shows the standard lipidA/core/O-antigen model, and its structure has been elucidated by Carlson and colleagues (30). A lipid-A part is coupled to an acidic core, consisting of a tri- and a tetrasaccharide. The O-antigen part of RBL5523 LPS most probably consists of repeating units of D-glucose and quinovosamine (2-amino-2,6-dideoxy-D-glucose). The latter observation is of interest, since RBL5523 originally is a clover symbiote and clover lectin-mediated agglutination has been reported to be inhibited by addition of quinovosamine (31). RBL5523 LPS is not a ligand for PSL (22). This is consistent with data from permethylation analysis, showing that glucose residues present in LPS are primarily 1-4-linked (Laus and Carlson, unpublished result). The composition of the O-antigen chain of rhizobial LPS is strain- rather than species-specific, whereas the core composition of R.leguminosarum LPS is conserved among the various biovars of the species.

\section{GPS}

Only in the stationary phase of growth, RBL5523 produces a gelling surface polysaccharide (GPS). This neutral polysaccharide has been discovered and characterized by Zevenhuizen and van Neerven (32). Its production may be limited to $R$. leguminosarum biovars. GPS consists of repeating units with glucose, mannose and galactose in a 1:1:4 ratio. As judged from the structure, one of the mannose residues is a potential PSL ligand. However, in precipitation tests GPS did not bind to PSL. Binding of the suggested mannose may be prevented by steric hindrance. The function of GPS is unknown. It is poorly soluble in water, and may protect the bacteria under stress conditions.

\section{Glucomannan}

Recently, we discovered that RBL5523 produces a glucomannan (GM) that co-purifies with LPS (22). The structure of this neutral polysaccharide is currently under investigation. GM appeared to be an excellent PSL ligand. Labeling with fluorescent PSL showed that GM is present at one of the poles of the bacterium. It is this pole which contacts the root hair surface during attachment. Because RBL5523 is derived from a
いはヒドロキシル基とリポ多糖 (LPS) との間の疎水性相互作用 の可能性がある。現在のところ、感染線維形成において EPS と CPS のどちらかが必要なのか、あるいは両方が必要なのかは確 認できない。EPS/CPS 欠損変異株では感染中心の数が減少する ことから、根毛先端への接着性が低下していると判断される (28)。CPS カプセルが細菌表面のセルロース線維を遮蔽し、セル ロースを介した細菌の凝集を妨げる可能性がある。

\section{LPS}

根粒細菌はグラム陰性細菌であり、外膜にはりポ多糖 (LPS) が含まれる。R. leguminosarum の LPS は標準的なりピド A / コ ア / O-抗原モデルに合致し、その構造は Carlson と共同研究者 によって解明された (30)。リピド A 部分は三糖あるいは四糖か らなる酸性のコアに結合している。RBL5523 の LPS の O-抗原 部分は、㧍そらく D-グルコースとキノボサミン (2-amino-2,6dideoxy-D-glucose) の繰り返し構造からなる。後者の存在は興味 深い。RBL5523 は元来はクローバーの共生体であり、クロー バーレクチンにより凝集するが、キノボサミンを添加すると阻 害されるという報告があるからである (31)。RBL5523 LPS は

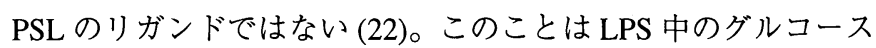
残基は主として 1-4 結合で存在するという過メチル化分析のデー 夕とも合致する (Laus and Carlson、未発表デー夕)。根粒細菌 LPS 中の O-抗原は種特異的というょりは株特異的であるが、 $R$. leguminosarum の LPS のコア組成は様々な biovars 種において保 存されている。

\section{GPS}

RBL5523 は生育の定常期においてのみゲル化する表面多糖 (GPS)を生産する。この中性の多糖はZevenhuizen と van Neerven により発見され解明された(32)。このものは R. leguminosarum biovarsに限って生産されるらしい。GPS はグルコース、マン ノース、ガラクトーが $1: 1: 4$ の比率をもつ繰り返し単位から なっている。構造から判断すると、マンノース残基の 1 つはPSL のリガンドとなりうる。しかし沈降テストでは GPS は PSLに 結合しなかった。結合すると思われていたマンノースは立体障 害を受けている可能性がある。GPS の役割はわかっていない。 これは水に溶けにくく、細菌をストレス条件下で保護している のかもしれない。

\section{グルコマンナン}

最近、われわれは RBL5523 がLPS と共に精製されるグル

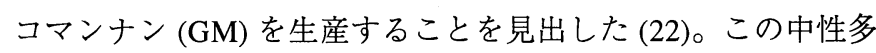
糖の構造は研究途上である。GM は PSLのリガンドとして最適 のように思える。蛍光性の PSL 誘導体で染色することにより、 $\mathrm{GM}$ が細菌の一方の極に存在することがわかった。この極がま さに根毛表面と接触する部位である。RBL5523 がクローバーの 
clover symbiote, and a nod gene-deficient mutant as well as the wild type clover-nodulating strain also produce GM, GM can not be considered a biovar viciae-specific polysaccharide. An LPS-associated glucan produced by another $R l v$ strain has been reported by Planqué and Kijne (33).

\section{$\beta-1,2$-glucan}

Many Rhizobium species produce and secrete a cyclic $\beta$ 1,2 -glucan, and RBL5523 is not an exception. This glucan has been shown to be involved in osmoregulation. EPS-, CPS-, and LPS-deficiencies often result in increased glucan secretion (34). Absence of the glucan somehow results in inactivation of rhicadhesin and poor attachment properties (35). Although its structure shows glucose residues with potentially good PSL-binding properties, the glucan yields negative results in PSL-binding tests (27).

\section{Cellulose}

Rhizobia synthesize cellulose, $\beta$-1,4-glucan, in the form of long extracellular fibrils (18). Fibril-overproducing mutants show greatly enhanced aggregation at the root hair surface, including root hair tips. In comparison with other $R l v$ strains, RBL5523 behaves like a fibril-overproducing mutant, which flocculates during batch culture. Cellulose-negative mutants normally nodulate, but have lost the ability to infect long fastgrowing root hairs (22). Cellulose is not a PSL-ligand which is obvious from its structure.

\section{Rhizobial Surface}

The data presented above demonstrate that surroundings and surface of a Rhizobium cell are characterized by a fascinating fine mosaic of oligo- and polysaccharide molecules, the majority of which at some point being involved in the nodulation process. Obviously the Nod factors, lipochitin oligosaccharides, form part of this picture. It should be noted that biovar viceae Nod factors, such as produced by RBL5523, can not bind to PSL (36). Nod factors consist of a $\beta-1,4$-glucosamine backbone of which only the nonreducing residue is a potential PSL ligand. However, with $R l v$ strains this residue is O-acetylated at C6 which precludes PSL binding.

Characterization of the rhizobial saccharide coat has been made possible by laborious purification efforts and the study of specific mutants. The latter approach is complicated by the fact that a carbohydrate-processing enzyme can be involved in biosynthesis or transport of different polysaccharides. For example, galactose is present in EPS/CPS, LPS, GPS and GM of RBL5223. Consequently, the RBL5223 mutant exoB that can not synthesize galactose by a deficiency in UDP-glucose 4'epimerase (37) is affected in each of these polysaccharides. To our knowledge, the exoB mutant is the first well-characterized rhizobial mutant not able to attach to vetch root hairs under op-
共生体に由来すること、またクローバーに根粒を形成させる野 生株と同様に、nod 遺伝子欠損変異体も GM を生産することか ら、GM は biovar viceiae 特異的多糖とは考元られない。別の $R l v$ 株が産生している、LPS と結合した状態にあるグルカンを Planque と Kijne が報告している (33)。

\section{$\beta$-1,2-グルカン}

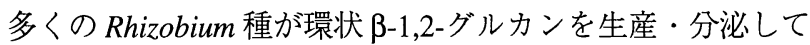
おり、RBL5523 も例外ではない。このグルカンは浸透圧調節に 関わることが知られていた。EPS、CPS、LPS が欠損するとしば しばグルカン分泌が増大する (34)。グルカンが存在しないとリ カドヘジンの不活性化や接着不全が起こりがちになる (35)。こ のグルカンは構造からはPLS とよく結合しそうに見えるが、 PLS 結合テストでは否定的な結果しか得られていない (27)。

セルロース

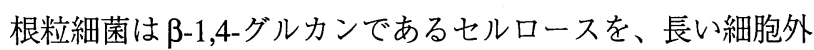
線維として合成する (18)。線維を過剩に生産する変異体は先端 も含めた根毛表面で著しい凝集を示す。他の $R l v$ 株と比較する と、RB5523 は線維を過剩に生産する変異体と同様な挙動をと り、バッチ培養中に凝集を起こす。セルロースを生産しない変 異株も正常に根粒を作るが、成長の早い長い根毛に感染する能 力を失っている (22)。七ルロースはその構造からして PSLのリ ガンドではない。

\section{D. 根粒細菌の表面}

以上のデータから、根粒細菌の周辺および表面は、オリゴ 糖および多糖がつくり出す緻密なモザイクのような状態にあ り、その大半の部分がなんらかのかたちで根粒形成に関与して いることがわかる。リポキチンオリゴ糖である Nod 因子も明ら かに一役買っている。RGL5523 が生産している biivar viceaeの Nod 因子が PSL に結合できないことは注目すべきである (36)。 Nod 因子は $\beta-1,4-$ グルコサミン骨格からなっているが、PSLの リガンドになりうるのは非還元末端のみである。しかし $R l v$ 株 ではこの残基の C6 は O-アセチル化されており、PSL との結合 はありえない。

根粒細菌を被覆している糖の性質は、多大な労力を要した 精製と特定の変異株の研究で明かにされてきた。变異株を使う 研究法は、糖鎖を加工する酵素がいくつもの多糖の生合成およ び輸送に関与しているために複雑になる。例えば、ガラクトー スはRBL523の EPS/CPS、LPS、GM 中に存在する。その結果、 RBL523 の変異体で UDP-グルコース 4'-エピメラーゼを欠損す る exoBでは、これらの多糖のどれもが影響を受けている (37)。 知る限りにおいて、exoB 变異体は、根粒を形成できる最適条件 下でもカラスノエンドウの根毛に接着できない根粒細菌の変異 体として、初めてよく研究されたものである (22)。EPS/CPS、 
timal nodulation conditions (22). Because EPS/CPS, LPS and GPS are not considered to be essential for attachment, this observation points at $\mathrm{GM}$ as a putative attachment factor. Bacteria deficient in a carbohydrate-processing enzyme may also be affected in synthesis of downstream products. For example, an exo5 mutant unable to synthesize glucuronic acid is also unable to produce galacturonic acid (22). To our knowledge, glucuronic acid is only present in EPS/CPS. Thus, the RBL5223 mutant exo5 is an EPS/CPS mutant but it also lacks galacturonic residues in the core of the LPS molecule. Increased sensitivity of this strain to hydrophobic compounds as compared to other EPS/CPS-deficient strains suggests a role of these acidic LPS moieties in outer membrane stability. Specific mutant strains possess mutations in saccharide-specific glycosyl transferases, e.g. the $p s s D / E$ mutant (38). Such mutants deserve special attention for elucidation of the role of these polysaccharides in nodulation. Now that purification procedures for each of the surface polysaccharides are available, analysis of more $R l v$ mutants will reveal their history, their interactions and their role in the nodulation process.

Composition of the carbohydrate coat varies with growth conditions and culture age (e.g., 39). For example, EPS is primarily produced during logarithmic growth and in the presence of sufficient nutritional carbon, whereas GPS is only produced during stationary growth. Interestingly, Candy lectins may influence the rhizobial surface coat. Mody and Modi (40) reported that treatment of certain strains of peanut rhizobia with a Galtype Candy lectin from peanut plants stimulated the synthesis of extracellular and capsular polysaccharides.

\section{E. Role of Candy Lectins}

Candy lectins are primarily produced in legume seeds. Apparently, binding of rhizobia is not the only function of these proteins. With regard to PSL, pea plants contain only one functional gene, $p s l(41,42)$. Consequently, activities in seeds, roots and other parts of the plant concern the same protein (43). High expression of the $p s l$ gene in seeds is possible by an essential control element in the $p s l$ promoter, W1 $(44,45)$. Control elements specifically required for expression of $p s l$ in roots and root hairs have not yet been identified.

Like all Candy lectins, PSL is a secretory protein. In seeds, the protein is secreted into the extracellular matrix and, in a large amount, into vacuoles during the process of seed maturation. Root hairs secrete PSL into the rhizosphere. However, presence of PSL on root hair tips (15) shows that plant cells can retain PSL at their surface. Putative binding sites can be located in the extracellular matrix or on the plasma membrane. The latter location has been visualized by Díaz. Using confocal scanning microscopy, she demonstrated the presence of PSL on the plasma membrane of plasmolysed pea root hairs (15).

For a secretory protein, PSL is remarkably hydrophobic.
LPS、GPS は接着に不可欠とは考えられていないので、この結 果は接着因子候補が $\mathrm{GM}$ だということを示唆している。また糖 鎖加工酵素を欠損した細菌では、下流の生産物の合成が影響を 受けている可能性がある。例えば、グルクロン酸を合成できな いexo5 変異体はガラクツロン酸も合成できない (22)。知る限り では、グルクロン酸は EPS/CPS にのみ存在する。したがって RB5223 の exo5 変異体は EPS/CPS に関する変異体であり、か つ LPS 分子中のコアのガラクッロン酸残基も欠損している。こ の変異株の踈水性化合物に対する感受性が、他の EPS/CPS 欠損 変異体に比べて増大していることから、これらの酸性 LPS 部分 が外膜の安定性に寄与していることが示唆される。特異的糖転 移酵素に関して变異をもつ变異株として、例えば $p s s / E$ がある が(38)、このような変異体は根粒形成におけるこれら多糖の役 割を解明するうえで注目してよい。表面多糖の各成分を精製す る方法が確立されてきたので、いろいろな $R l v$ 変異体を解析す れば、それぞれの表面多糖の歴史、相互作用、根粒形成におけ る役割がわかってくるであろう。

被覆糖質の組成は生育条件や培養期間によって変動する(例 えば 39)。例えば、炭素源が十分に供給されれば、先ず対数期に EPS が生産されるが、GPS は定常期でのみ生産される。面白い ことに、Candy レクチンは根粒細菌表面の被覆に影響を与える らしい。ピーナッッの根粒細菌の株の一つを、ピーナッッ由来 の Gal 型の Candy レクチンで処理したところ、細胞外㧍よびカ プセルの多糖の合成が促進されたと Modu と Modi が報告して いる (40)。

\section{E. Candy レクチンの役割}

Candyレクチンは主にマメの種子で作られる。これらタンパ ク質の役割が根粒細菌の結合のためだけとは思えない。PSLに 関して言えば、エンドウには機能のある遺伝子としては 1 つの $p s l$ しかない $(41 、 42) 。 そ の$ 結果、この植物では、種子、根、そ の他の部位で、レクチン活性を示すのは同じタンパク質である (43)。種子中で $p s l$ 遺伝子が高発現されるのは、 $p s l$ のプロモー ターである W1内にある必須調節要素の働きと考えられる (44、 45)。根抢よび根毛に扔ける $p s l$ の特異的発現のために必要な調 節要素はまだ確認されていない。

すべての Candy レクチンと同様に、PSL は分泌タンパク質 である。種子が成熟する過程で、細胞外マトリックスへ、また 液胞に多量に分泌される。根毛はPSLを根の周辺に分泌する。 しかし根毛先端に PSL が存在するので、植物細胞はPSLを根 毛表面に保持することもできる。細胞外マトリックスあるいは 細胞膜で、レクチンの結合部位と考えられる場所を検出するこ とが可能である。後者については Díazが可視化した。共焦点走 查型顕微鏡を用いて、彼女は原形質を除去したエンドウの根毛 の細胞膜上にPSL が存在することを実証した (15)。

分泌タンパク質としては PSL は疎水性がきわめて高い。 
Trends in Glycoscience and Glycotechnology Vol.16 No.90 (July 2004) pp.281-290

Like LPS, PSL is retained on a polymyxin-B agarose column (Laus and Logman, unpublished result). The protein can insert nonspecifically into a phospholipid monolayer (46). This suggests that after secretion from the plant cell, a number of PSL molecules stay in the plant membrane environment. In this location, PSL is not only able to bind foreign ligands but also endogenous ligands such as glycolipids and glycosylphosphatidylinositol (GPI-) anchors. Thereby, PSL can contribute to membrane raft formation and to modulation of membrane properties. In seeds, membrane modulation by PSL may contribute to storage of proteins and to survival of the vacuolar membrane during the seed drying process. Recently, a likely candidate for the legume receptor of Nod factors was identified as a LysM-type membrane receptor $(1,2)$. Such receptor molecules are known to function in concert with other proteins. Candy lectins as well as exogenous lectin ligands, such as GM, may be involved in regulation of signal transduction at the legume root hair surface. In a preliminary experiment in our laboratory, PSL showed to be able to interact with the membrane glycolipid D-glucosyl- $\beta$-1,1'-D-erythro-sphingosine (Logman, unpublished result). This interaction could be partially inhibited by the addition of 3-O-methyl-D-glucose, a PSL hapten. In our opinion, this research area will provide the clue to the function of Candy lectins in plants. It will also answer the question how rhizobial lectin-binding oligosaccharides stimulate root hair infection $(8,47)$.

\section{F. Transgenic Plants}

Well-characterized Candy lectin knock-out mutants of legumes are not (yet) available. Hirsch and colleagues were the first to create a Candy lectin knock-out by use of the anti-sense strategy (48). Interestingly, alfalfa plants deficient for the root lectin Mslec1 showed abundant nodulation, even better than control plants. Before drawing conclusions from these experiments, the role of alfalfa lectins and rhizobial surface polysaccharides in the alfalfa root nodule symbiosis should be established first. Mslec1-antisense plants showed various developmental abnormalities, consistent with an endogenous role for Candy lectins in legume plants.

In gain-of-function experiments, Díaz and Van Rhijn transferred Candy lectin genes to nonhost legumes. Díaz et al. $(49,50)$ found that pea rhizobia, including RBL5523, infect root hairs of transgenic (hairy) clover roots and induce nodule-like structures and (few) nodules, in contrast to the situation in control roots. Van Rhijn et al. (51) transformed lotus plants with Le1, the gene encoding soybean Candy lectin, to find an enhanced response of the transgenic roots to soybean rhizobia, including root hair curling and root cell divisions. Also alfalfa roots, transgenic for $p s l$, were readily infected by pea rhizobia, provided that they produced alfalfa-specific Nod factors (52). These results are consistent with a role for Candy lectin in nodu-
LPS と同様にPSL はポリミキシン-B アガロースカラムに吸着 される (Laus and Logman、未発表)。またリン脂質の単分子膜に 非特異的に埋め込まれる (46)。このことから、植物細胞から分 泌された後、多数の PSL 分子が植物の膜環境に止まると示唆さ れる。このような局在状態において、PSLは外部のリガンドば かりか、糖脂質や GPI アンカーなどのような内部リガンドとも 結合しうる。したがって PSL は膜のラフト形成や膜特性の変調 にも貢献しうる。種子においては、PSLによる膜の変調は、夕 ンパク質の貯蔵に貢献し、また種子が乾燥する過程において、 液胞の膜の延命にも貢献するであろう。Nod 因子のマメ側のレ セプターの候補が LysM 型膜レセプターであることが最近に

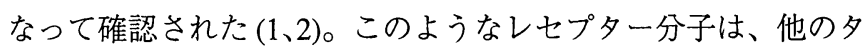
ンパク質と協調して働くことが知られている。GMのような細 胞外のレクチンリガンドと共に、Candy レクチンはマメの根毛 表面において、シグナル伝達の調節に関与しているのであろ う。われわれの研究室での予備的実験によれば、PSLは膜の糖 脂質 D-グルコシル- $\beta-1,1$ '-D-エリスロ-スフィンゴシンと相互作用 できることがわかった (Logman、未発表)。この相互作用はPSL のハプテンである 3-O-メチル-D-グルコースを添加すれば部分的 に阻害できる。この研究は植物における Candy レクチンの機能 を解く鍵となると信じている。また根粒細菌のレクチン結合性 オリゴ糖が、いかにして根毛への感染を促進するかについても 解答を与えるであろう $(8 、 47)$ 。

\section{F. トンスジェニック植物}

Candy レクチンをノックアウトしたマメ科植物で詳しく研 究されたものはまだない。Hirsch と共同研究者はアンチセンス 法によって、Candy レクチンのノックアウト体を初めて作った (48)。興味深いことに、根のレクチン Mslec1 を欠損したアル ファルファは、対照植物よりも沢山の根粒を形成した。これら の実験から結論を下す以前に、アルファルファレクチンと根粒 細菌表面多糖が、根粒に扔ける共生に対してどのような役割を 果たしているのかを先ず解明する必要がある。Mslec1 アンチセ ンス植物は様々な発生上の異常を示すので、Candy レクチンが マメ科植物自体に対してもなんらかの役割を果たすと考えてお かしくない。

Díaz と Van Rhijn は、機能回復実験によって、Candy レク チン遺伝子を非宿主植物に導入した。彼らはRBL5523を含む工 ンドウの根粒細菌が、トランスジェニック (毛状) クローバーの 根に感染し、対照の根と比べて、根粒に似た構造体や、ごく少 数であるが根粒を誘導することを発見した (49、50)。Van Rhijn ら は、ダイズの Candy レクチンをコードする遺伝子 Lel を使っ て、八ス科植物を形質転換させ、その根について、根毛のカー ル形成および細胞分裂も含めて、ダイズの根粒細菌に対する応 答性が向上することを見出した (51)。エンドウの根粒細菌がア ルファルファ特異的 Nod 因子を生産する場合には、psl で形質 転換されたアルファルファの根にも、この細菌が容易に感染し た (52)。これらの結果から、Candy レクチンは根粒形成に役割 を果たしていると考えておかしくない。この観察は根粒細菌の 
lation. The observations can be explained by an improved association of the rhizobia with the root hair surface (through surface ligands such as GM or EPS/CPS for B. japonicum [39]) and/or by membrane modulation by the heterologous lectin, facilitating root infection.
根毛表面への集合性が向上したこと (B. japonicum の場合、GM、 EPS/CPS などの表面リガンドを介して)、あるいは外来のレクチ ンによる根への感染を促進するような膜の変調によって説明で きるであろう。

帝京大学薬学部生化学教室

笠井 献一 訳

\section{References}

1. Radutoiu, S., Madsen, L. H., Madsen, E. B., Felle, H. H., Umehara, Y., Gronlund, M., Sato, S., Nakamura, Y., Tabata, S., Sandal, N., and Stougaard, J. (2003) Nature(London) 425, 585-592

2. Limpens, E., Franken, C., Smit, P., Willemse, J., Bisseling, T., and Geurts, R. (2003) Science 302, 630-633

3. van Batenburg, F. H. D., Jonker, R., and Kijne, J. W. (1986) Physiol. Plant. 66, 476-480

4. Rathbun, E. A., Naldrett, M. J., and Brewin, N. J. (2002) Mol. Plant-Microbe Interact. 15, 350-359

5. van Brussel, A. A. N., Bakhuizen, R., van Spronsen, P. C., Spaink, H. P., Tak, T., Lugtenberg, B. J. J., and Kijne, J. W. (1992) Science 257, 7072

6. van Spronsen, P. C., Gronlund, M., Pacios, B. C., Spaink, H. P., and Kijne, J. W. (2001) Mol. Plant-Microbe Interact. 14, 839-847

7. Kijne, J. W. (1992) in Biological Nitrogen Fixation (Stacey, G., Burris, R. H., \& Evans, H. J. eds.) pp. 349-398, Chapman and Hall, New York, London

8. Dazzo, F. B., Truchet, G. L., Sherwood, J. E., Hrabak, E. M., Abe, M., and Pankratz, S. H. (1984) Appl. Environ. Microbiol. 48, 1140-1150

9. Smit, G., Swart, S., Lugtenberg, B. J. J., and Kijne, J. W. (1992) Mol. Microbiol. 6, 2897-2903

10. Matthysse, A. G. \& Kijne, J. W. (1998) in The Rhizobiaceae; molecular biology of model plant-associated bacteria (Spaink, H. P., Kondorosi, A., \& Hooykaas, P. J. J. eds.) pp. 235-249, Kluwer academic publishers, Dordrecht/Boston/London

11. Smit, G., Logman, T. J. J., Boerrigter, M. E. T. I., Kijne, J. W., and Lugtenberg, B. J. J. (1989) J. Bacteriol. 171, 4054-4062

12. Morris, V. J., Brownsey, G. J., Harris, J. E., Gunning, A. P., Stevens, B. J. H., and Johnston, A. W. B. (1989) Carbohydr. Res. 191, 315-320

13. Peumans, W. J., and Van Damme, E. J. (1995) Plant Physiol. 109, 347-352

14. Van Eijsden, R. R., Hoedemaeker, F. J., Diaz, C. L., Lugtenberg, B. J., de Pater, B. S., and Kijne, J. W. (1992) Plant Mol. Biol. 20, 1049-1058

15. Díaz, C. L., Logman, T. J. J., Stam, H. C., and Kijne, J. W. (1995) Plant Physiol. 109, 1167-1177

16. Bohlool, B. B., and Schmidt, E. L. (1974) Science 185, 269-271

17. Kijne, J. W., Smit, G., Diaz, C. L., and Lugtenberg, B. J. J. (1988) J. Bacteriol. 170, 2994-3000

18. Smit, G., Kijne, J. W., and Lugtenberg, B. J. J. (1986) J. Bacteriol. 168, 821-827

19. Smit, G., Kijne, J. W., and Lugtenberg, B. J. J. (1987) J. Bacteriol. 169, 4294-4301

20. Vesper, S. J., and Bauer, W. D. (1986) Appl. Environ. Microbiol. 52, 134-141

21. Vesper, S. J., Malik, N. S., and Bauer, W. D. (1987) Appl. Environ. Microbiol. 53, 1959-1961

22. Laus, M. C. (2004) PhD Thesis, Leiden University

23. Swart, S. (1994) PhD Thesis, Leiden University

24. Jansson, P.-E., Kenne, L., Lindberg, B., Ljunggren, H., Lonngren, J., Ruden, U., and Svensson, S. (1977) J. Am. Chem. Soc. 99, 3812-3815

25. Robertsen, B. K., Åman, P., Darvill, A. G., McNeil, M., and Albersheim, P. (1981) Plant Physiol. 67, 389-400

26. O’Neill, M. A., Darvill, A. G., and Albersheim, P. (1991) J. Biol. Chem. 266, 9549-9555

27. van der Schaal, I. A. M., Logman, T. J. J., Diáz, C. L., and Kijne, J. W. (1984) Anal. Biochem. 140, 48-55

28. van Workum, W. A. T., van Slageren, S., van Brussel, A. A. N., and Kijne, J. W. (1998) Mol. Plant-Microbe Interact. 11, $1233-1241$

29. Canter Cremers, H. C. J., Batley, M., Redmond, J. W., Wijfjes, A. H. M., Lugtenberg, B. J. J., and Wijffelman, C. A. (1991) J. Biol. Chem. 266, 9556-9564

30. Kannenberg, E. L., Reuhs, B. L., Forsberg, L. S. \& Carlson, R. W. (1998) in The Rhizobiaceae: molecular biology of model plant-associated bacteria (Spaink, H. P., Kondorosi, A., \& Hooykaas, P. J. J. eds.) pp. 119-154, Kluwer academic publishers, Dordrecht/Boston/London

31. Hrabak, E. M., Urbano, M. R., and Dazzo, F. B. (1981) J. Bacteriol. 148, 697-711

32. Zevenhuizen, L. P. T. M., and van Neerven, A. R. W. (1983) Carbohydr. Res. 124, 166-171

33. Planqué, K., and Kijne, J. W. (1977) FEBS Lett. 73, 64-66

34. Breedveld, M. W., Canter Cremers, H. C. J., Batley, M., Posthumus, M. A., Zevenhuizen, L. P. T. M., Wijffelman, C. A., and Zehnder, A. J. B. (1993) J. Bacteriol. 175, 750-757

35. Swart, S., Smit, G., Lugtenberg, B. J. J., and Kijne, J. W. (1993) Mol. Microbiol. 10, 597-605

36. Kijne, J. W., Diaz, C., van Eijsden, R., Booij, P., Demel, R., van Workum, W., Wijffelman, C., Spaink, H. P., Lugtenberg, B. \& de Pater, S. (1994) in Proceedings of the 1st European Nitrogen Fixation conference (Kiss, G. B. \& Endre, G. eds.) pp. 106-110, Officina Press, Szeged, Hungary

37. Canter Cremers, H. C. J., Batley, M., Redmond, J. W., Eydems, L., Breedveld, M. W., Zevenhuizen, L. P. T. M., Pees, E., Wijffelman, C. A., and Lugtenberg, B. J. J. (1990) J. Biol. Chem. 265, 21122-21127

38. van Workum, W. A. T., Canter Cremers, H. C. J., Wijfjes, A. H. M., van der Kolk, C., Wijffelman, C. A., and Kijne, J. W. (1997) Mol. PlantMicrobe Interact. 10, 290-301

39. Mort, A. J., and Bauer, W. D. (1980) Plant Physiol. 66, 158-163

40. Mody, B., and Modi, V. (1987) J. Biosci. 12, 289-296

41. Gatehouse, J. A., Bown, D., Evans, I. M., Gatehouse, L. N., Jobes, D., Preston, P., and Croy, R. R. (1987) Nucleic Acids Res. 15, 7642

42. Kaminski, P. A., Buffard, D., and Strosberg, A. D. (1987) Plant Mol. Biol. 9, 497-507

43. Hoedemaeker, F. J., Richardson, M., Diaz, C. L., de Pater, B. S., and Kijne, J. W. (1994) Plant Mol. Biol. 24, 75-81 
44. de Pater, S., Pham, K., Klitsie, I., and Kijne, J. W. (1996) Plant Mol. Biol. 32, 515-523

45. de Pater, S., Pham, K., Chua, N. H., Memelink, J., and Kijne, J. W. (1993) Plant Cell 5, 877-886

46. Booij, P., Demel, R. A., de Pater, B. S., and Kijne, J. W. (1996) Plant Mol. Biol. 31, 169-173

47. Abe, M., Sherwood, J. E., Hollingsworth, R. I., and Dazzo, F. B. (1984) J. Bacteriol. 160, 517-520

48. Brill, L. M., Fujishige, N. A., Hackworth, C. A., and Hirsch, A. M. (2004) Mol. Plant-Microbe Interact. 17, 16-26

49. Díaz, C. L., Melchers, L. S., Hooykaas, P. J. J., Lugtenberg, B. J. J., and Kijne, J. W. (1989) Nature(London) 338, 579-581

50. Díaz, C. L., Spaink, H. P., Wijffelman, C. A., and Kijne, J. W. (1995) Mol. Plant-Microbe Interact. 8, 348-356

51. van Rhijn, P., Goldberg, R. B., and Hirsch, A. M. (1998) Plant Cell 10, 1233-1250

52. van Rhijn, P., Fujishige, N. A., Lim, P. O., and Hirsch, A. M. (2001) Plant Physiol 126, 133-144

Received on May 24, 2004, accepted on June 10, 2004

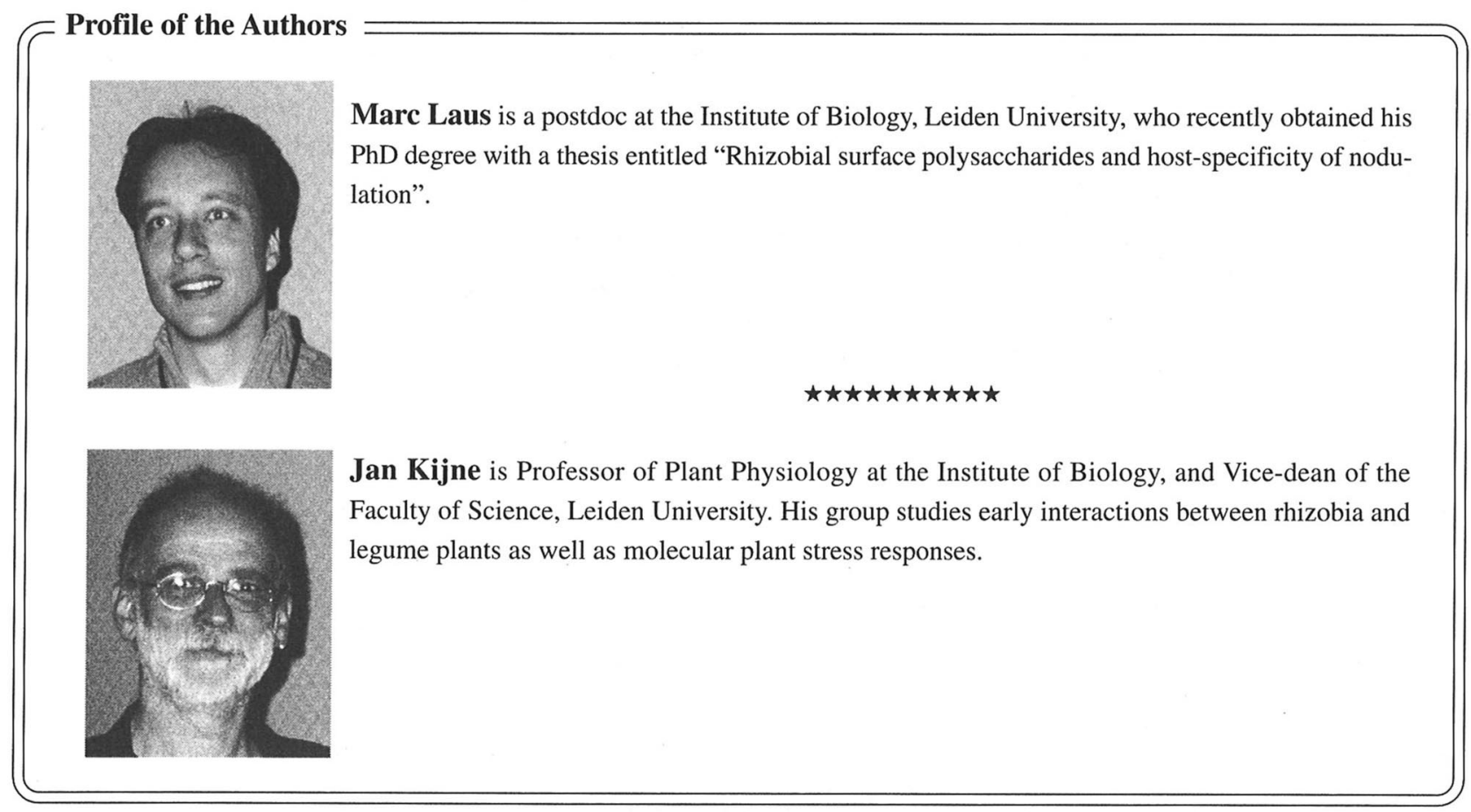

